\title{
An Error Analysis of English Sentence Construction in Writing Subject
}

\author{
Evi Agustina Sari ${ }^{1, *}$ Sri Gustiani ${ }^{1}$, Yusri Yusri ${ }^{1}$, Tiur Simanjuntak ${ }^{1}$ \\ ${ }^{1}$ Sriwijaya State Polytechnics \\ *Corresponding author. Email: eviagustinasari@polsri.ac.id
}

\begin{abstract}
The purposes of the present study were to know the types of errors found in English sentences constructed by the students of the English Department at Sriwijaya State Polytechnics. Two hundred pieces of writing written by a hundred students from fifty students in the first year, twenty-five students in the second year, and twenty-five students in the third year of the academic years 2020/2021 were taken as the data of the study. They were collected and analyzed in terms of the grammar errors using the Linguistic Category Taxonomy and the Surface Strategy Taxonomy. The results showed that the most frequently committed errors were omission of articles, third-person singular verb incorrect, the substitution of singulars for plurals, misuse of a-preposition, disagreement of subject and verb, the substitution of simple non-past, use of wrong possessive, omission of the verb to be, simple verb use instead of -ing, and misformation of passive sentences. This errors study provides teachers, syllabus designers, and test developers to determine their way of teaching or materials in the process of language teaching and learning. In addition, the most common errors and the ways to overcome them must be tackled by using various and interesting materials in English Structure textbooks with exercises and skills related to the grammatical errors.
\end{abstract}

Keywords: English Sentence Construction, Error Analysis, Grammar Errors, Types of Errors in Writing

\section{INTRODUCTION}

Learning the English language is the same as learning grammar. Without grammar, language would be chaotic and produce communication problem, such as grammatical errors both in writing and speaking [1]. Grammar means the sounds and sound patterns, the basic units of meaning, such as words, and the rules to combine them to form new sentences [2]. There are sets of rules needed to know and to be applied in constructing sentences. Sentence construction is considered grammatically correct when the students write sentences based on the rules of the English language. Students need to have and improve their knowledge of grammar to avoid grammatical errors in their writing.

To decrease grammatical errors in constructing sentences for their writing, students need to improve their knowledge of grammar. They need to have full command of grammatical concepts to avoid grammatical errors. Stress grammar instruction decrease errors, so many students demand grammar instruction because it fulfils cultural expectations [3]. Some cultures place great value on grammatical correctness. Moreover, they say that presentation of grammar to

learners can facilitate learning in several ways and one of them is it can present high-frequency grammatical items explicitly to speed up learning. In addition, a benefit of grammar instruction may therefore be the corrective feedback that the students receive on their performance [4].

The English Department at Sriwijaya State polytechnic put the course of Structure (Grammar) in its curriculum. It is delivered to students for three semesters. However, the materials for the Structure instruction need to be developed. The grammatical items are not selected and sequenced, for different teachers are teaching the structure for each semester. The grammatical items for the course of Structure given to the students are not based on the problems which students have with their English grammar. Moreover, there are many grammatical items to be given to students due to the need for proper language skill competencies. Grammatical items cover units of 
meaning, parts of speech, structural elements of a sentence, and other grammatical terms.

In designing the grammar component of a course, an error analysis is a useful tool in suggesting appropriate grammatical items to be selected and sequenced in a

grammar course. Having error analysis, teachers are able to have insights into the learner main problems with English and the useful descriptions of these available [5]. Furthermore, the descriptions form a database for the selection of items in courses for upperintermediate and advanced learners in which the grammar component aims to help students to refine the accuracy of their English production.

Knowing the errors that had been made by the students in their writing, it is potential to equip with the selected and effective materials based on their needs for the course of Structure. Hence, it is important to know what types of errors are found in the English sentences constructed by the students of the English Department of Sriwijaya State Polytechnics. In this pandemic era, the learning materials were developed based on online learning and this research will be made in the form of online courses.

\section{LITERATURE REVIEW}

\subsection{The Description of Errors}

Errors are produced during the learning by the learners as a characteristic of linguistic system at a given stage of learning as systematic, consistent deviance. [6] in [7]. Errors are also parts of conversation or composition that deviate from some selected norm of mature language performance [8]. Usually, foreign language learners without proficient in the language will made errors in their sentence [9] cited in [1]. Errors can reveal learners' insufficient competence in producing sentences with correct grammar [11] in [7].

There are some distinguished factors that cause errors. The first is the performance factor resulting from fatigue and inattention and then the competence factor as a result of lack of knowledge [12]. Errors are indicated significant in three different ways. First, they tell teachers how far towards the goal the learners have advanced and consequently, and what remains for them to learn. Second, they provide researchers the evidence of how language is learnt, and strategies the learners are employing in their language discovery. Thirdly, they are important device to the learners themselves, as regard for the learners to learn [9] cited in [13].

\subsection{Sources of Errors}

As formulated by [11], there were four sources of errors, i.e.: interlingual transfer, intralingual transfer, the context of learning, and communicative strategies. While [6] also states four major categories of errors. They are interlingual errors, intralingual errors, communication strategy-based errors, and induced errors. First, the interlingual transfer is grammar rules transfer from the native language of the learners to the second language. Furthermore, the native language is

the only linguistic system which the learner can draw before the system of the second language is familiar [11]. There is a relationship between difference and difficulty, the greater the difference the greater the difficulty [14].

Then, the intralingual transfer occurs within the target language itself. The learners ignore the target language form and engage their learning strategies that can be the source of error [6]. Furthermore, he explains the errors that are made by the learners based on the learning strategy. They are false analogy, misanalysis, incomplete rule application, exploiting redundancy, overlooking co-occurrence restrictions, hypercorrection, and overgeneralization. In addition, errors of over generalization are a negative intralingual transfer. The examples are the errors in producing the main verb following an auxiliary given by [15] cited in [11]. Next, [16] provided typical English intralingual errors in the use of articles. They are the omission of the, the use of the instead of $\varnothing$, the use of a instead of the, the use of a instead of $\varnothing$, the omission of a. There are four main causes of intralingual errors namely overgeneralization, ignorance of rule restrictions, incomplete application of rules, and false concepts hypothesized [17].

The third source of error is the context of learning

[11] is the same with induced errors [18] in [6]. This source of error refers to learner errors that result from the classroom situation such as the teacher who delivers the materials, the materials in the case of school learning (textbook), or the social situation in the case of untutored second language learning. In addition, [6] states that students often make errors because of being misled by how the teachers give definitions, examples, explanations, and arrange practice opportunities (for example a memorized drill but not properly contextualized). Both teacher and textbook can cause faulty hypotheses for the learner to make about the language in a classroom context,. Furthermore, [6] mentions that sources of induced errors are materialsinduced error, teacher-talk induced error, exercisebased induced error, errors induced by pedagogical priorities, and look-up errors. 
The last source of learner error is communication strategies. Communication strategies provide processes of interlingual and intralingual transfer and context of learning when a learner is trying to get a message across to a hearer or reader [11]. In addition, [6] divides communication strategy-based errors into holistic and analytic strategies. Holistic strategies refer to using another near-equivalent L2 item that learners have learnt because of lacking the required form (approximation). The concept indirectly is expressed analytic strategies by allusion rather than by direct reference (circumlocution)

\subsection{Concept of Error Analysis}

Making errors was seen as a sign of mislearning and regarded as undesirable to proper process learning A lack of understanding is learner's error reflection that underlying competence in the language that he/she is learning [19] in [13]. The error identification is conducted by observing, analysing, and classifying. It is done to reveal something of the system operating within the learner leads to error analysis [20] in [13]. Strategies of second language learners could be inferred through the error analysis that could be helpful for the second language learning researchers.

Error Analysis (EA) is the process of determining the incidence, nature, causes, and consequences of unsuccessful language [6]. Furthermore, he refers to error analysis as the analysis of learners' errors by comparing what the learners have learned with what they lack. In addition, [21] cited in [22] to the study of linguistic ignorance, the investigation of what people do not know and how they attempt to cope with their ignorance. The errors analysis method analyses errors made by learners of EFL and ESL [8]. It helps reveal the strategies used by learners to learn a language, and assists teachers to know what difficulties improve their teaching.

Errors were viewed as valuable information for three beneficiaries: for teachers, it clues them on the progress of the students; for researchers, it provides evidence as to how language is acquired or learned; for learners themselves, it gives them resources to learn [9]. EA is also confirmed beneficial that can let teachers prepare accurate and precise teachings which are suitable for their students [24].

\section{RESEARCH METHODOLOGY}

\subsection{Method}

This research applied a qualitative and descriptive research design. These types of research have begun to be increasingly used in the field of second language teaching and learning [26]. It is stated that qualitative research is a type of social science research that collects and works with non-numerical data (text, video, or audio) and that seeks to understand the meaning, concepts, opinions, or experiences from these data [27]. Moreover, content analysis was applied as the method of this qualitative research. Content analysis is describing and categorizing common words, phrases, and ideas in qualitative data. A descriptive research design aims to investigate one or more variables [28]. It does not control or manipulate any of the variables, but only observes and measures them. In a descriptive research design, the data may be collected qualitatively, but it is often analyzed quantitatively, using frequencies, percentages, averages, or other statistical analyses to determine relationships [26]. The data of this research were analyzed quantitatively because frequencies and percentages are used to know the number of errors made by the students.

\subsection{Place and Time}

This research was conducted in the English Department at State Polytechnic of Sriwijaya Palembang. This research was lasted for 6 months, from March to September 2021 of the academic year 2020- 2021.

\subsection{Population and Sample}

The population of this research is all students of the English department of the three- academic year period from 2018-2020. The sampling technique used simple random sampling. The sample was 50 students from the first year, 25 students from the second year, and 25 students from the third year. Two pieces of writings about tourism destination in South Sumatera and housekeeping activities from each student was analyzed, and the total number of the writings is 200 pieces of writings.

\subsection{Research Procedure}

In doing this research, the writers conducted the following steps. First, the writers asked the students to write paragraphs with the topics of tourism destinations in South Sumatera and housekeeping activities. Then the writers analyzed the errors the students made in their writings by using the theory of the Linguistic Category Taxonomy and the Surface Strategy Taxonomy as a reporting tool of the errors collected [8]. They say that Linguistic Category Taxonomy classifies errors based on both language components like phonology, syntax and morphology, semantics and lexicon (meaning and vocabulary), and discourse or the particular linguistic constituent the errors affect. [29] cited in [8] developed Linguistic Category Taxonomy for morphology and syntax. Another linguistic category taxonomy was developed by

[30] that focused on clauses and sentences and the Surface Strategy Taxonomy was developed by [8]. It categorizes errors into omission, addition, misformation, and misorderings. The Surface Strategy Taxonomy categorizes the errors into omissions, additions (double 
markings and simple addition), misformation (over regularization, and archi-forms or alternating forms), and mis-orderings. After that, the writers will classify the errors based on their types and make the order of relative frequency of the types of error from the most to the least frequent. And the last, the writers will describe which linguistic categories that those types of errors belong to.

\subsection{Data Collection Technique}

The method used in collecting the data in this research is the secondary research method. The secondary research refers to collecting existing data in the form of texts, images, audio or video recording, etc [27]. The data will be obtained from the students' writings. There will be 200 pieces of writing constructed by 100 students. This research was constructed on the grammatical errors found in the students' written work.

\subsection{Data Analysis Technique}

The students' writings will be evaluated using the theory of Linguistic Category Taxonomy and Surface Strategy Taxonomy. The data obtained from the students' work will be recorded in descriptive terms using a checklist. Errors will be classified into two types of errors: in morphology that includes the incorrect use of articles, possessive case, a third-person singular verb, simple past tense, past participle, comparative adjective/adverb; in syntax that covers noun phrase, verb phrase, verb and verb construction, word order and some transformation. After the identification, the frequency of each kind of error will be calculated and the results will be displayed in the form of a table to present the number of errors and percentage. The errors will be then discussed in detail with examples of each type. To get the data in the form of a percentage, the obtained data will be calculated by using the following formula.

$$
\begin{aligned}
& \mathrm{P}=\underline{\mathrm{F}} \times 100 \% \\
& \mathrm{P}=\text { Percentage } \\
& \mathrm{F}=\text { Frequency of error occurred } \\
& \mathrm{N}=\text { Total numbers of errors }
\end{aligned}
$$

The result of the calculation of the errors will be put in tables and will be interpreted based on the types of errors and their linguistic categories

\section{RESULTS AND ANALYSIS}

\subsection{Results}

First, Based on the result of the analysis, it was found that there was a total number of 217 grammatical errors in the sentences constructed by the students. In analyzing the error, the writers used the Surface
Strategy Taxonomy developed by [8] and the Linguistic Category Taxonomy developed by [29] [30].

From the error analysis using the Surface Strategy Taxonomy, it was found that there were 107 omission errors, 95 misformation errors, and 15 addition errors. The most frequent type of error that was made by the students was an omission. The omission is one type of error that refers to the absence of a grammatical item that must appear in a well-formed sentence. There were 107 errors for this error type of omission. Misformation is the use of the wrong form of the morpheme or structure, while addition error refers to the presence of an item which must not appear in a well-formed sentence. The classification of the error frequency $(\mathrm{F})$ and percentage $(\%)$ which was based on the Surface Strategy Taxonomy is shown in the following table (see Table 1).

Table 1. The Classification of Errors Based on the Surface Strategy Taxonomy

\begin{tabular}{|l|l|c|c|}
\hline No & \multicolumn{1}{|c|}{ Error Types } & $F$ & $\%$ \\
\hline 1 & Omission & 107 & $49 \%$ \\
\hline 2 & Misformation & 95 & $44 \%$ \\
\hline 3 & Addition & 15 & $7 \%$ \\
\hline Total & & 217 & $100 \%$ \\
\hline
\end{tabular}

For the error type of omission, the students made eight kinds of omission errors. They are omissions of an article, third-person singular, plurals, irregular and past tense, the verb to be (copula), prepositions, subject of sentences, and auxiliaries do/is/are. The omission of articles was the most dominant error that was made by the students. It was followed with the omission error of third-person singular, the omission of plurals, irregular and regular past tense, the verb to be (copula), prepositions, the omission of the surrogate subject, and auxiliary do, is/are. The following table (Table 2) shows the errors of omission with the linguistic categories

Table 2. The Classification of the Omission Errors

\begin{tabular}{|l|c|c|}
\hline \multicolumn{1}{|c|}{ Linguistic Category } & $\mathrm{F}$ & $\%$ \\
\hline Omissions of article & 29 & $27 \%$ \\
\hline Omission of third person singular & 23 & $21 \%$ \\
\hline Omissions of plurals & 20 & $19 \%$ \\
\hline $\begin{array}{l}\text { Omissions of irregular and regular } \\
\text { past tense }\end{array}$ & 13 & $12 \%$ \\
\hline Omissions of verb to be (copula) & 11 & $10 \%$ \\
\hline Omissions of prepositions & 6 & $6 \%$ \\
\hline Omissions of surrogate subject & 3 & $3 \%$ \\
\hline Omissions of auxiliary do, is/are & 2 & $2 \%$ \\
\hline Total & 107 & $100 \%$ \\
\hline
\end{tabular}

For the misformation errors, it was found that there were 11 kinds of misformation errors made by the students. They are misformation of preposition, passive sentences, possessive pronouns, misformation of using

-ing form, verb construction, auxiliary system, gerunds after prepositions, plural nouns, regular past, quantifier, and regular past participle. The most 
dominant error was misformation of prepositions. The classification of the misformation errors was shown in the table below (Table 3).

Table 3. The Classification of the Mis-formation Errors

\begin{tabular}{|l|c|c|}
\hline \multicolumn{1}{|c|}{ Linguistic Category } & $\mathrm{F}$ & $\%$ \\
\hline Misformations of prepositions & 18 & $19 \%$ \\
\hline Misformations of passive sentences & 15 & $16 \%$ \\
\hline Misformations of possessive pronouns & 12 & $13 \%$ \\
\hline Misformations of using -ing form & 11 & $12 \%$ \\
\hline Misformations of verb construction & 9 & $10 \%$ \\
\hline Misformations of auxiliary system & 7 & $7 \%$ \\
\hline $\begin{array}{l}\text { Misformations of gerunds after } \\
\text { prepositions }\end{array}$ & 7 & $7 \%$ \\
\hline Misformations of plural nouns & 5 & $5 \%$ \\
\hline Misformations of regular past & 5 & $5 \%$ \\
\hline Misformations of quantifier & 3 & $3 \%$ \\
\hline Misformations of regular past participle & 3 & $3 \%$ \\
\hline Total & 95 & $100 \%$ \\
\hline
\end{tabular}

For the addition error, it was found that the error was a simple addition of third-person singular and was presented in Table 4.

Table 4. The Classification of the Addition Errors

\begin{tabular}{|l|c|c|c|}
\hline Linguistic Category & $\mathrm{F}$ & $\%$ \\
\hline $\begin{array}{l}\text { Simple additions of third person } \\
\text { singular }\end{array}$ & 15 & $100 \%$ \\
\hline Total & 15 & $100 \%$ \\
\hline
\end{tabular}

From the analysis that used the Linguistic Category Taxonomy, it was obtained that there were 21 kinds of grammatical errors among 217 errors. The grammatical errors were mainly in the categories of Morphology, Syntax, Sentential Complements, Passive Sentences, and the Auxiliary System. There were 4 kinds of errors in the category of Morphology, 12 kinds of errors in the Syntax, 2 in the Sentential Complements, 2 in the Passive Sentences, and 1 in the Auxiliary System. The whole grammatical errors were shown and ranked in the following table (Table 5).

Table 5. The Classification of Error Types Based on the Linguistic Category Taxonomy.

\begin{tabular}{|c|l|c|c|}
\hline No & \multicolumn{1}{|c|}{ Linguistic Category } & $\mathrm{F}$ & $\%$ \\
\hline 1 & Omission of the article & 29 & $13.4 \%$ \\
\hline 2 & $\begin{array}{l}\text { Third person singular verb } \\
\text { incorrect }\end{array}$ & 23 & $10.6 \%$ \\
\hline 3 & $\begin{array}{l}\text { Substitution of singulars for } \\
\text { plurals }\end{array}$ & 20 & $9.2 \%$ \\
\hline 4 & Misuse of preposition & 18 & $8.3 \%$ \\
\hline 5 & $\begin{array}{l}\text { Disagreement of subject and verb } \\
\text { (subject and number) }\end{array}$ & 15 & $7 \%$ \\
\hline 6 & Substitution of simple non past & 13 & $6.1 \%$ \\
\hline 7 & Use of wrong possessive & 12 & $5.5 \%$ \\
\hline 8 & Omission of verb to be & 11 & $5.1 \%$ \\
\hline 9 & $\begin{array}{l}\text { Simple verb uses instead of } \\
\text {-ing }\end{array}$ & 11 & $5.1 \%$ \\
\hline 10 & Active order but passive form & 10 & $4.6 \%$ \\
\hline 11 & $\begin{array}{l}\text { Attachment of the past marker to } \\
\text { the dependent verb }\end{array}$ & 9 & $4.2 \%$ \\
\hline 12 & $\begin{array}{l}\text { Misformation of the next verbal } \\
\text { word }\end{array}$ & 7 & $3.2 \%$ \\
\hline 13 & Misformation of gerunds after & 7 & $3.2 \%$ \\
\hline
\end{tabular}

\begin{tabular}{|c|l|r|c|}
\hline & preposition & & \\
\hline 14 & Omission of preposition & 6 & $2.9 \%$ \\
\hline 15 & Regularization by adding -ed & 5 & $2.3 \%$ \\
\hline 16 & Substitution of plurals for singulars & 5 & $2.3 \%$ \\
\hline 17 & Misformation of passive verbs & 5 & $2.3 \%$ \\
\hline 18 & $\begin{array}{l}\text { Past participle incorrect (omission } \\
\text { of -ed) }\end{array}$ & 3 & $1.4 \%$ \\
\hline 19 & Misformation of quantifier & 3 & $1.4 \%$ \\
\hline 20 & Omission of surrogate subject & 3 & $1.4 \%$ \\
\hline 21 & $\begin{array}{l}\text { Formation of no or not without the } \\
\text { auxiliary do }\end{array}$ & 2 & $0.5 \%$ \\
\hline & Total & 217 & $100 \%$ \\
\hline
\end{tabular}

Based on the Linguistic Category Taxonomy developed by [29] as cited in [8], it was found that the errors were categorized into Morphology and Syntax. In the Morphology category, the errors were third person singular verb incorrect, the substitution of simple nonpast, regularization by adding - ed, and past participle incorrect (omission of -ed). There were 12 kinds of errors in the Syntax category. They are the omission of the article, omission of the verb to be, the substitution of singulars for plurals, simple verb used instead of -ing, formation of no or not without the auxiliary do, attachment of the past marker to the dependent verb, the substitution of plurals for singulars, omission of preposition, misuse of the preposition, use of wrong possessive, disagreement of subject and verb (subject and number), and misformation of quantifier.

In The Linguistic Category Taxonomy developed by [30], the error categories were Sentential Complement, Passive Sentences, and Auxiliary System. In the Sentential Complement category, there is misformation of gerunds after preposition and omission of the surrogate subject. In the Passive Sentences category, the errors are active order but passive form and Misformation of passive verbs. The last was the error in the Auxiliary System. It was misformation of the next verbal word.

The followings are the ten types of errors that were frequently committed by the students and found to be the students' greatest difficulties.

\subsubsection{Omission of Article}

The omission of the article was the first dominant error made by the students. It was 29 errors. There were 24 errors of omission of article a/an and 5 in the omission of article the. For example, When I was child (correct: When I was a child) and in English Department (correct: in the English Department).

\subsubsection{Third-Person Singular Verb Incorrect}

Third person singular verb incorrect was the error in the second rank made by the students. There were 23 errors. The students failed to attach $-\mathrm{s}$ in the third person singular verbs. For example, He always follow 
me (correct: He always follows me) and It need much money (correct: It needs much money)

\subsubsection{Substitution of Singular for Plurals}

The third dominant error was the substitution of singular for plurals. This error was grouped into misformation error of plurals. There were 20 errors made by the students. For example, There are many kind of.... (correct: There are many kinds of. ) and We had some problem on the way (correct: We had some problems on the way)

\subsubsection{Misuse of Preposition}

There were 18 errors made by the students in using the preposition. There were 14 errors in applying unnecessary prepositions in the sentences. And it was found that the students made 4 errors in using prepositions correctly. For example, We visit to an extreme place (correct: We visit an extreme place) and We smile to him (correct: We smile at him)

\subsubsection{Disagreement of Subject and Verb (Subject and Number)}

The disagreement of Subject and Verb (Subject and Number) was an error in the fifth rank made by the students. There were fifteen errors committed by the students in constructing sentences. Thirteen errors were the sentence construction with the plural subject and singular verb form and two errors were vice versa. For example, Laptops comes in various resolutions (correct: Laptops come in various resolution) and I win later and are sent (correct: I win later and am sent).

\subsubsection{Substitution of Simple Non Past}

There were 13 errors in the Substitution of Simple Non-Past. The students wrote simple verb forms instead of the past verb form. They made 11 errors in constructing compound and complex sentences and 2 errors in simple sentences with the past verbs. For example, When I was a collegian, I have ever become a daily worker (correct: When I was a collegian, I had ever become a daily worker) and It is the last event we had a big success (correct: It was the last event we had a big success.)

\subsubsection{Use of Wrong Possessive}

The disagreement of Subject and Verb (Subject and The students made 12 errors of using the wrong possessive. There were 10 errors in the use of possessive nouns. Possessive nouns are used to express ownership of an object by adding an apostrophe. The students made 2 errors in the use of possessive adjectives. The possessive adjective does not agree with the subject pronouns. For example, They will still provide the best service for the recovery of his patients (it should be their not his).

\subsubsection{Omission of Verb To Be}

There were 11 errors in constructing sentences with the verb to be. The students omitted the verb to be in their sentence construction. For example, My house full with water (correct: My house was full with water) and She in a hurry (correct: She is in a hurry).

\subsubsection{Simple Verb Use instead of Verb -ing}

The students made 11 errors in constructing a subject and an object of a sentence using verbs in a simple verb form instead of verb -ing form. For example, make a schedule of working (correct: making a schedule of working) and The first reason is have more rest time (correct: The first reason is having more rest time.)

\subsubsection{Problems with Formation of Passive Sentences}

The errors were the students constructed passive sentences with active order but passive form. There were 10 errors made by the students related to the formation of passive sentences. For example, I was stayed in the hotel (correct: I stayed in the hotel) and The restrooms are smells bad (correct: The restrooms smell bad).

\subsection{Discussion}

Based on the analysis, it is found that the students committed many errors in different areas of grammar. Making errors is a part of learning and learners cannot learn the language without first systematically committing errors [8]. As learners work out new rules, these have to be integrated into their knowledge of English grammar and this information has to be restructured as the learner moves to another stage of development [5].

Among the categories (addition, omission, selection, and ordering) given by [9] cited in [31] and the categories (omission, addition, misformation, and misordering) given by [8], omission errors hold the most dominant errors committed by the students. There are 107 errors in omission errors, 95 errors in misformation, 15 fifteen in addition errors, and no errors in mis-ordering errors. According to [8], the most common error is omitting grammatical morphemes. Moreover, they say that omission errors are found in greater abundance and across a greater variety of morphemes during the early stages of L2 acquisition. 
Omission of articles is in the first rank of errors made by the students. Omission of the article is categorized as intra-lingual errors in the use of article. The errors in the use of articles are commonly encountered in English learners from different native language background [16] [11].

Omission of third person singular verb incorrect, plurals, and omission of irregular and regular past tense are in the second, third, and fourth ranks of errors respectively. The most important are third- singular $-\mathrm{s}$, plural $-\mathrm{s}$, past tense -ed, and progressive - ing. Language learners omit grammatical morphemes much more frequently than content words [8]. Within the set of grammatical morphemes, it has been observed that verb to be(copula), the -ing marker, simple past tense, and third-person markers are likely to be omitted.

\section{CONCLUSION}

Studying the nature of errors enables teachers of the English language and researchers to have a better understanding of the linguistic area where learners have the most difficulty in constructing English sentences. The data provided from the analysis of students' errors will help teachers, syllabus designers, and test developers to determine their way of teaching or materials in the process of language teaching and learning. The data of errors form a database for the selection of grammatical items in Structure Course material design. They should make use of such studies to acquire new techniques and insights and specially to develop materials for the Course of English Structure. Moreover, teachers of the English language should focus on the most common errors and try to overcome them by using various and interesting materials to design textbooks for the Course of English Structure with exercises and skills related to the grammatical errors.

\section{REFERENCES}

[1] [1] S. Rana, L.A. Owaidh, and N.A. Harbi. Grammatical Errors in English Writing Made by Senior Students of English Department at Jubail University College: Problem Analysis, Reasons and Solutions. International Journal of Arts and Commerce, 8(5), 2019, pp. 23-34.

[2] V. Fromkin, R. Rodman, and N. Hyams. An Introduction to language, 7th ed. Boston: Thomson, Wadsworth, 2003.

[3] R. L. Oxford. Integrated Skills in the ESL/EFL Classroom. ERIC Digest. September 2001. Retrieved at 03 November 2021 from https://files.eric.ed.gov/fulltext/ED456670.pdf
[4] D. L. Freeman. Teaching Grammar. In M. Celcemurcia (Ed.). Teaching English as a Second or Foreign Language. Boston, MA: Heinle \& Heinle, 2001.

[5] T. Hedge. Teaching and Learning in the Language Classroom. New York: Oxford University Press, 2000.

[6] C. James. Errors in Language Learning and Use: Exploring Error Analysis. New York: Routledge, Taylor \& Francis Group. 2013.

[7] S. M. Misuari. Causes and Effects of grammar Errors. 2017. Retrieved from www.slideshare.net.

[8] F. Kuiken, and I. Vedder. Speaking and writing tasks and their effects on second language performance. In S. M. Gass, and A. Mackey (Eds). The Routledge Handbook of Second Language Acquisition, New York: Routledge, Taylor \& Francis Group. 2012. pp. 364-377.

[9] S. P. Corder. The Significance of Learners' Errors. International Review of Applied Linguistic. 5 (4), 1967, pp. 161-170.

[10] Abdalhussein, Dr. M. Subakir, M. H. Fahim. Grammatical Error Analysis of Iraqi Postgraduate Students' Academic Writing: The Case of Iraqi Students in UKM. International Journal of Education and Research 3(6), 2015, pp. 20-23

[11] H. D. Brown. Principles of Language Learning and Teaching, 4th ed. New Jersey: Prentice Hall, Inc, 2000 .

[12] N. Chomsky. Aspects of the Theory of Syntax. Cambridge, Massachusetts: M.I.T. Press, 1965.

[13] C.O. Ewie, and M. R. Williams. Grammatical and Lexical Errors in Students' English Composition Writing: The Case of Three Senior High Schools (SHS) in the Central Region of Ghana - College of Languages Education, University of Education, Winneba, Ghana Sino-US English Teaching, 14(8), 2017, pp. 463-482.

[14] C. Kramsch. Re-reading Robert Lado, 1957, Linguistic across Cultures. Applied Linguistics for language teachers. International Journal of Applied Linguistics, $\quad 23 \quad$ July 2007. https://doi.org/10.1111/j.1473-4192.2007.00149.x

[15] B. Taylor. The Use of Overgeneralization and Transfer Learning Strategies by Elementary and Intermediate University Students Learning ESL. Washington, D.C.: TESOL, 1975.

[16] J. C. Richards. Error Analysis: Perspective on second language acquisition New York: Routledge. 2015 
[17] C. Lamsiu. An Analysis of Grammatical Errors in Srinakharinwirot University Student's Writing, 2014. Retrieved from http://ir.swu.ac.th /xmlui/bitstream/handle/123456789/3671

/Chada_I.pdf?sequence $=1$

[18] K. Rustipa. Contrastive Analysis, Error Analysis, Interlanguage and the Implication to Language Teaching. Ragam, Jurnal Pengembangan Humaniora 11(1), 2011, pp.17-22.

[19] M. Mezrag. The importance of error analysis in the learners' writing skill: The case of first year English students at Biskra University, 2013. (Dissertation submitted in partial fulfilment of the requirements for the Master Degree in Science of Language, Biskra University).

[20] M. Sampong. Error analysis. Thammasat Review, 16(2), 2014, pp.109-127.

[21] D. Crystal. The penguin dictionary of language (2nd ed.). London: Penguin Books, 1999.

[22] N. Amara. 58 Errors Correction in Foreign Language Teaching. The Online Journal of New Horizons in Education 5 (3), 2015, pp. 1-5.

[23] R. Carter, and D. Nunan. The Cambridge Guide to Teaching English to Speakers of Other Languages. New York: Cambridge University Press, 2001.

[24] A. Hinnon. Common errors in English writing and suggested solutions of Thai university students, 2004.
[25] K. Sermsook, J. Liamnimitr, and R. Pochakorn. An Analysis of Errors in Written English Sentences: A Case Study of Thai EFL Students 1 Department of English. English Language Teaching; 10 (3), 2017, pp. 5-8.

[26] H. Nassaji. Qualitative and Descriptive Research: Data Type Versus Data Analysis. Language Teaching Research, 19(2), 2015, pp. 129-132

[27] P. Bhandari. An Introduction to Qualitative Research, 2020. Retrieved from Info@ scibber,com.

[28] S. McCombes. Descriptive Research. date updated, January 132020.

[29] R. Politzer and A. Ramirez. An Error Analysis of the Spoken English of Mexican-American Pupils in A Bilingual School and A monolingual School. Language Learning, 23(1), 1973.

[30] M. Burt and C. Kiparsky. The Goofican: A Repair Manual for English. Rowley, Ma: Newbury House, 1972.

[31] A. Jabeen, B. Kazemian, and M.S. Mustafai. The Role of Error Analysis in Teaching and Learning of Second and Foreign Language. Education and Linguistic Research; 1(2), 2015, pp. 56-70 